\title{
Determination of Subsurface Stormflow Velocity Using Tracer
}

\author{
S.S. Adarsh ${ }^{1 *}$, Jyothy Narayanan ${ }^{1}$ and Sathian ${ }^{2}$ \\ ${ }^{1}$ Kelappaji College of Agricultural Engineering \& Technology, Tavanur-679573, India \\ ${ }^{2}$ Department of Soil \& Water Conservation Engineering, Kelappaji College of Agricultural \\ Engineering \& Technology, Tavanur-679573, India \\ *Corresponding author
}

\section{A B S T R A C T}

Keywords

Subsurface stormflow, Interflow, Tracer hydrology, Subsurface runoff, Quick flow

Article Info

Accepted:

20 November 2019

Available Online:

10 December 2019
The subsurface stormflow is considered as the fast moving component of subsurface runoff of which only a little information is available due to its complex mechanism of movement through subsurface. Hence, this study has taken up for absorbing more knowledge on the phenomenon of subsurface stormflow with the help of tracer method. The experiment has carried out on an experimental plot in the KCAET campus, Kerala, India. The salt tracer experiment is carried out by line application $120 \mathrm{ppm}$ sodium chloride solution on a shallow trench upslope to an excavated through-flow trench. The EC values on the trench face are monitored using the TEROS 12 sensors at three depths $(0-40 \mathrm{~cm}, 40-80 \mathrm{~cm}$ and $80-120 \mathrm{~cm})$. The subsurface stormflow velocities through $0-40 \mathrm{~cm}, 40-80 \mathrm{~cm}$ and 80 $120 \mathrm{~cm}$ depths obtained were $27.27 \mathrm{~cm} \mathrm{day}^{-1}, 30 \mathrm{~cm}^{-1 a y}{ }^{-1}$ and $26.67 \mathrm{~cm}$ day $^{-1}$ respectively. It is found that the velocity of subsurface stormflow exhibits a negative correlation with the soil dry density.

\section{Introduction}

Water is considered as the most vital natural resource required for the survival of all the living organisms. So, all water resources should be managed precisely and judiciously. Unfortunately, scarcity of water can be felt all over the world, even in places with an abundance of annual precipitation. The state of Kerala is a typical example of a region or state in India facing droughts of varying degrees despite receiving high magnitude of annual rainfall. The state faces acute water shortage for various purposes including drinking during non-rainy seasons. This is because the groundwater potential of the terrain is not in accordance with the high rainfall magnitude and high infiltration rate of the topsoil. Therefore, it is to be inferred that a large portion of the infiltrated water is escaped 
from the vadose zone (root zone) region quickly after rainfall events.

Thetraditional hydrology suggests the flow of precipitated water on earth be of two types. They are surface flow and subsurface flow. The subsurface flow can be divided into quick flow and low flow components. The quick flow refers to subsurface stormflow and the low flow refers to base flow. Subsurface stormflow could be treated as the main process of storm runoff generation in the steep terrains having a humid environment with permeable soils (Anderson and Burt, 1990). The early studies of subsurface flow used trenches (or pits) combined with hydrometric approaches for its observation. The era of tracer hydrology started about years ago and developed slowly but fascinatingly. The factors average soil mantle depth, average land slope, the average number of large storms and land use will largely determine the response of small watersheds to storms within the humid region(Hewlett and Hibbert, 1967). The use of environmental isotopes as tracer made the hydrograph separation possible through tracer hydrology (Rodhe, 1981).With the knowledge on the phenomenon of subsurface stormflow the transport of chemical in interflow and runoff might be substantially reduced with appropriate management of relatively small soil surface and volume (Lehman and Ahuja, 1985).The tracer hydrology is also used to find the possible source area for the contamination of water bodies (Tirumalesh et al., 2007), the subsurface flow directions and to study the preferential connections between the surface catchmen t(Knoll and Scheytt, 2017).

The physiochemical parameters such as electrical conductivity (EC) and moisture content also can be treated as a relevant hydrological tracer (Leibundgut and Seibert, 2011). With the proper understanding on the process of subsurface stormflow, better water management and conservation practices will be possible. In this context, this study has been envisioned to throw more insight into the phenomenon of subsurface stormflow using tracer method

\section{Materials and Methods}

\section{Description of the study area}

The experiments for the study were conducted in the KCAET campus, Kerala, India. The study area comprises of lateritic terrain having sandy loam type of soil and a gentle slope. It is situated at $10 \mathrm{o} 51^{\prime} 18$ " $\mathrm{N}$ latitude and 750 59'11" E longitude at an altitude of $10 \mathrm{~m}$ above mean sea level. The average annual rainfall varies from 2500 to $2900 \mathrm{~mm}$. The average maximum temperature of study area is $31^{\circ} \mathrm{C}$ and average minimum temperature is 26 ${ }^{\circ} \mathrm{C}$. The slope map of the experimental site is given in Figure 1.

\section{Experimental setup}

The experimental setup has made by excavating a through-flow trench of $3 \mathrm{~m}$ length, $0.6 \mathrm{~m}$ width and $1.5 \mathrm{~m}$ depth on the study site across the general land slope, in order to intersect the subsurface flow coming from the upslope area. A small trench of length $0.5 \mathrm{~m}$, width $0.3 \mathrm{~m}$ and $0.3 \mathrm{~m}$ depth was also constructed at $2 \mathrm{~m}$ upslope to the through flow trench to facilitate the line application of tracer.

\section{Determination of soil physical properties}

The representative soil samples were collected from the profile depths $0-40 \mathrm{~cm}, 40-80 \mathrm{~cm}$ and $80-120 \mathrm{~cm}$ for the study site for the determination of physical properties such as bulk density, specific gravity and particle size distribution. The standard methodology used for determining the soil physical properties of the study area are given in Table 1 . 


\section{Obtaining the soil moisture curve}

In order to obtain the soil moisture curve for the study site for three different soil profile depths tensiometers were installed at the depths $0-40 \mathrm{~cm}, 40-80 \mathrm{~cm}$ and $80-120 \mathrm{~cm}$ on the trench face for each experimental plots. The variation in the moisture content is observed using TEROS 12 sensors and the corresponding soil suction is observed from the installed tensiometers. Later the soil water characteristic curves are made using the observations.

\section{Methodology}

Sodium chloride solution of $120 \mathrm{ppm}$ is prepared and used as tracer. The solution is applied into the small trench frequently. The background EC value for the tracer solution is also determined. The EC is measured using three TEROS 12 capacitive sensors each fixed between the depths $0-40 \mathrm{~cm}, 40-80 \mathrm{~cm}$ and $80-120 \mathrm{~cm}$ on the through-flow trench face. The three sensors are plugged to a ZL6 data logger for data collection, data storage and data download. The diagrams for the TEROS 12 sensor and the ZL6 data logger are shown in Figure 2 and 3, respectively. Line application of tracer into the small trench is done till the TEROS 12 sensors fixed at the trench face will detect the change in EC which indicates arrival of subsurface stormflow to the through-flow trench.

\section{Results and Discussion}

\section{Soil physical properties}

The soil physical properties for the study area are presented in Table 2.

\section{Soil suction data studies}

The soil suction variation according to the volumetric water content for the experimental site is given in Table 3.
From the soil suction variation data in accordance with volumetric water content, soil water characteristic curves for the experimental site is obtained and is shown in Figure 4.

The dry density for the experimental site was found minimum at $40-80 \mathrm{~cm}$ depth (1.11 $\mathrm{g} \mathrm{cm}^{-3}$ ) and maximum for $80-120 \mathrm{~cm}$ depth $\left(1.26 \mathrm{~g} \mathrm{~cm}^{-3}\right)$. From Figure 4, it is evident that, for the same moisture content the soil suction was found minimum for $40-80 \mathrm{~cm}$ depth. Therefore, the soil suction values and the soil dry density values are positively correlated. For the experimental site, soil suction and soil dry density are having a positive correlation between them. Hence the soil moisture suction increases with the increase in the soil dry density for the same moisture content. This is because the unit volume of the soil matrix with high dry density will have more soil particles for the suction of water particles compared to the unit volume of soil matrix with a lesser dry bulk density.

\section{Application of tracer}

For determining the velocity of subsurface stormflow through different depths, $120 \mathrm{ppm}$ of sodium chloride solution is applied to the shallow trench, $2 \mathrm{~m}$ upslope to the throughflow trench by filling the shallow trench with the tracer solution four times a day i.e. 451 of the sodium chloride solution is applied to the shallow trench at $6 \mathrm{am}, 10 \mathrm{am}, 2 \mathrm{pm}$ and $6 \mathrm{pm}$ in each day until a noticeable increase in the value of EC is detected by the TEROS 12 sensors fixed at the three depths on the trench face. The background EC value is also determined using the sensor. The background EC for the prepared sodium chloride solution was found to be $0.2210 \mathrm{mS} \mathrm{cm} \mathrm{cm}^{-1}$. The breakthrough curve for the tracer application is obtained for the trench face and is shown in Figure 5. 
By analysing the tracer breakthrough curve it was found that the peak values of $\mathrm{EC}$ for the depths $0-40 \mathrm{~cm}, 40-80 \mathrm{~cm}$ and $80-120 \mathrm{~cm}$ were obtained after $176 \mathrm{~h}, 160 \mathrm{~h}$ and $180 \mathrm{~h}$ respectively after the tracer application. Therefore, the velocity of subsurface stormflow through the depths 0-40 cm, 40-80 $\mathrm{cm}$ and $80-120 \mathrm{~cm}$ are calculated to be 27.27 $\mathrm{cm}$ day $^{-1}, 30 \mathrm{~cm} \mathrm{day}^{-1}$ and $26.67 \mathrm{~cm} \mathrm{day}^{-1}$ respectively. The subsurface stormflow velocity was maximum for the $40-80 \mathrm{~cm}$ deep soil layer.

The Figure 6 shows the subsurface stormflow velocity versus soil dry density graph. From that it is evident that the velocity of subsurface stormflow and the soil dry density are negatively correlated. This is because the soil layer having a high value of dry density will have greater number of soil particles compared to the soil layer having less dry bulk density. Therefore, the suction potential will be more on the former case than the latter. The pressure needed for initiating the fluid flow through the dense soil is less than that of light soil and hence the velocity of subsurface stormflow will be higher for the latter. Here the subsurface stormflow velocity and the soil dry density are negatively correlated. Thus the velocity of subsurface stormflow through $40-80 \mathrm{~cm}$ soil layer has got the higher value among the three layers.

Table.1 Soil physical properties and their method of determination

\begin{tabular}{|l|l|}
\hline Physical Property & Methodology \\
\hline Bulk density & Core cutter method \\
\hline Specific gravity & Pycnometer method \\
\hline $\begin{array}{l}\text { Soil Texture } \\
\text { Moisture content }\end{array}$ & $\begin{array}{l}\text { Sieve analysis } \\
\text { Oven drying and using TEROS 12 sensor }\end{array}$ \\
\hline
\end{tabular}

Table.2 Soil physical properties of the study site

\begin{tabular}{|l|c|c|c|}
\hline \multicolumn{1}{|c|}{ Physical Properties } & \multicolumn{3}{|c|}{ Soil Depth } \\
\cline { 2 - 4 } & $\mathbf{0 - 4 0} \mathbf{~ c m}$ & $\mathbf{4 0 - 8 0} \mathbf{~ c m}$ & $\mathbf{8 0 - 1 2 0} \mathbf{~ c m}$ \\
\hline Dry Density $\left(\mathbf{g ~ c m}^{-\mathbf{3}}\right)$ & 1.23 & 1.11 & 1.26 \\
\hline Specific Gravity & 2.42 & 2.49 & 2.54 \\
\hline Sand (\%) & 76.46 & 75.03 & 71.36 \\
\hline Silt (\%) & 18.40 & 19.70 & 22.47 \\
\hline Clay (\%) & 5.14 & 5.27 & 6.17 \\
\hline Soil Texture & Loamy fine sand & Sandy loam & Sandy loam \\
\hline Porosity & 0.49 & 0.55 & 0.50 \\
\hline Void Ratio & 0.96 & 1.22 & 1 \\
\hline
\end{tabular}


Table.3 Variation of soil suction with variation in volumetric water content

\begin{tabular}{|c|c|c|}
\hline Depth $(\mathrm{cm})$ & Soil Suction $(\mathrm{kPa})$ & Volumetric Moisture Content (\%) \\
\hline \multirow[t]{7}{*}{$0-40$} & 11 & 34.91 \\
\hline & 16 & 30.74 \\
\hline & 20 & 29.53 \\
\hline & 23 & 29.25 \\
\hline & 25 & 28.13 \\
\hline & 27 & 27.47 \\
\hline & 30 & 26.41 \\
\hline \multirow[t]{7}{*}{$40-80$} & 10 & 31.34 \\
\hline & 15 & 27.17 \\
\hline & 17 & 25.96 \\
\hline & 22 & 25.68 \\
\hline & 23 & 24.56 \\
\hline & 26 & 23.90 \\
\hline & 27 & 22.84 \\
\hline \multirow[t]{7}{*}{$80-120$} & 12 & 35.23 \\
\hline & 18 & 31.06 \\
\hline & 23 & 29.85 \\
\hline & 26 & 29.57 \\
\hline & 28 & 28.45 \\
\hline & 29 & 27.79 \\
\hline & 32 & 26.73 \\
\hline
\end{tabular}

Fig.1 Slope map of the study site

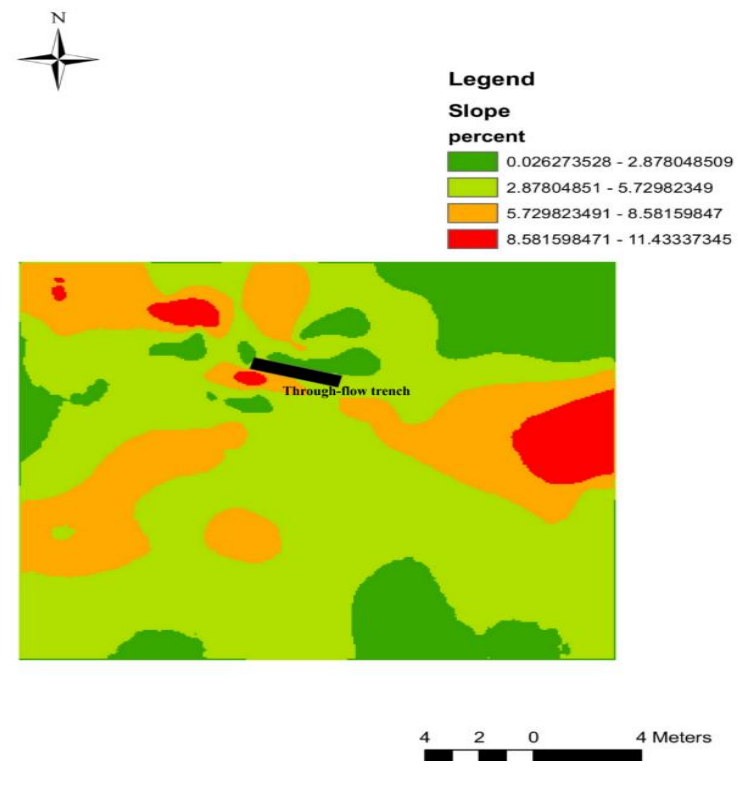


Fig.2 TEROS 12 capacitive sensor
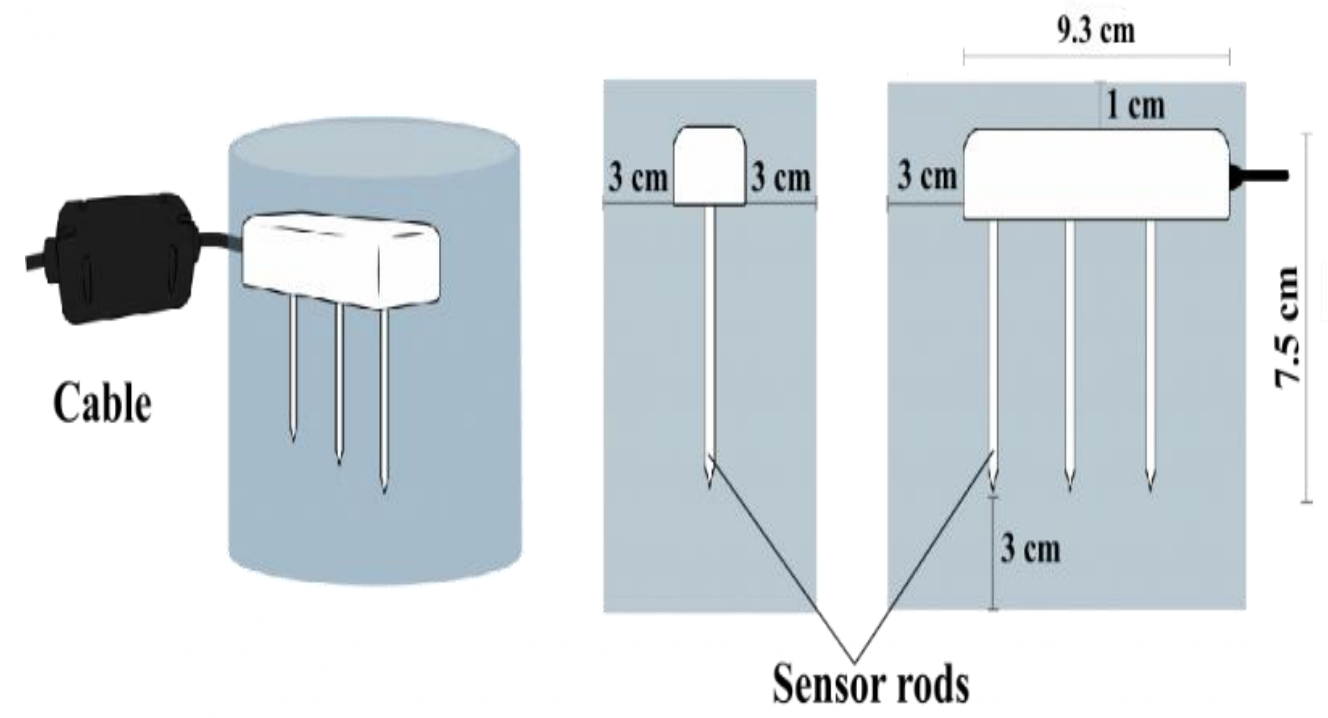

Fig.3 ZL6 data logger

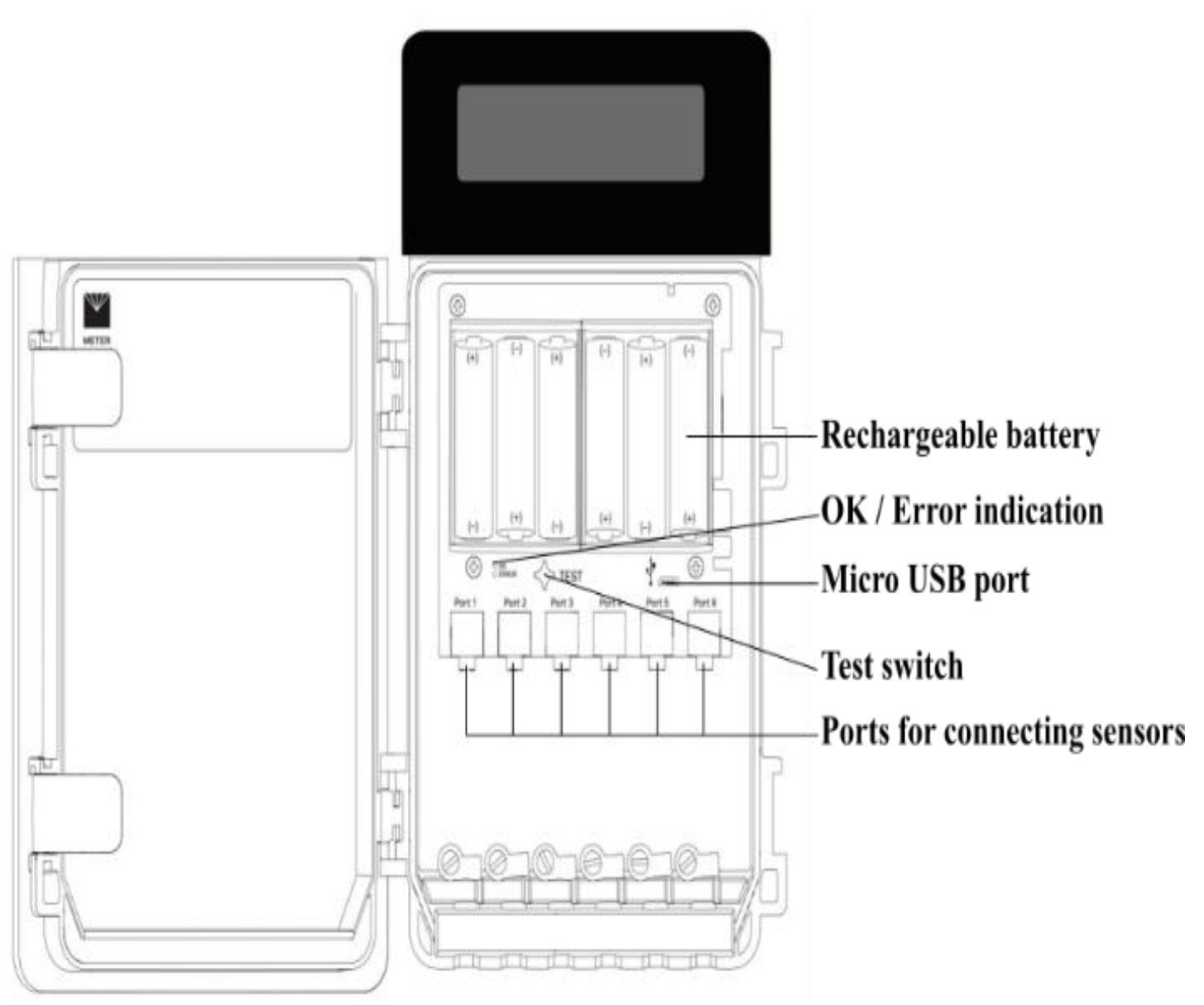


Fig.4 Soil water characteristic curve for the experimental site

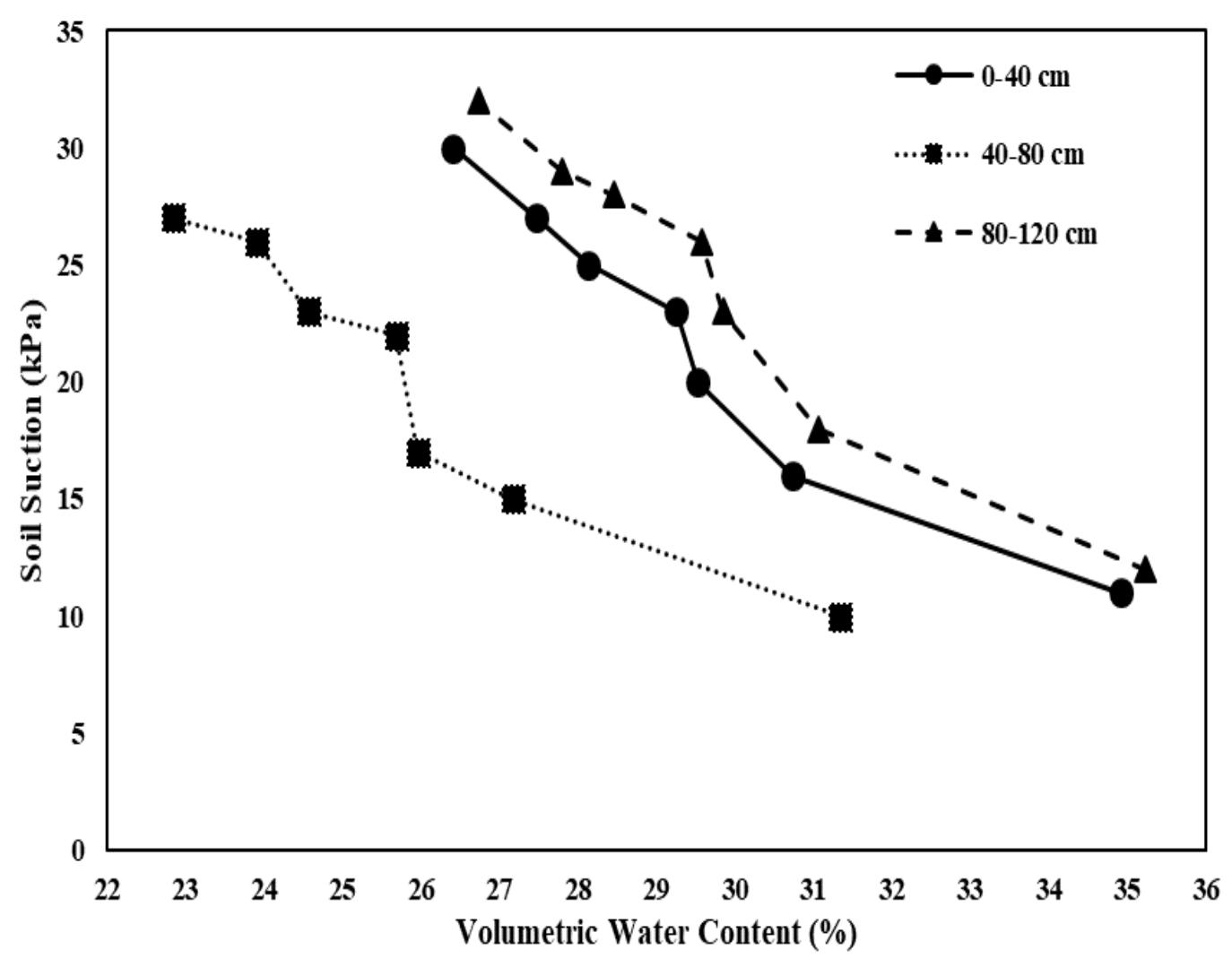

Fig.5 Tracer breakthrough curve for the trench face for different depths

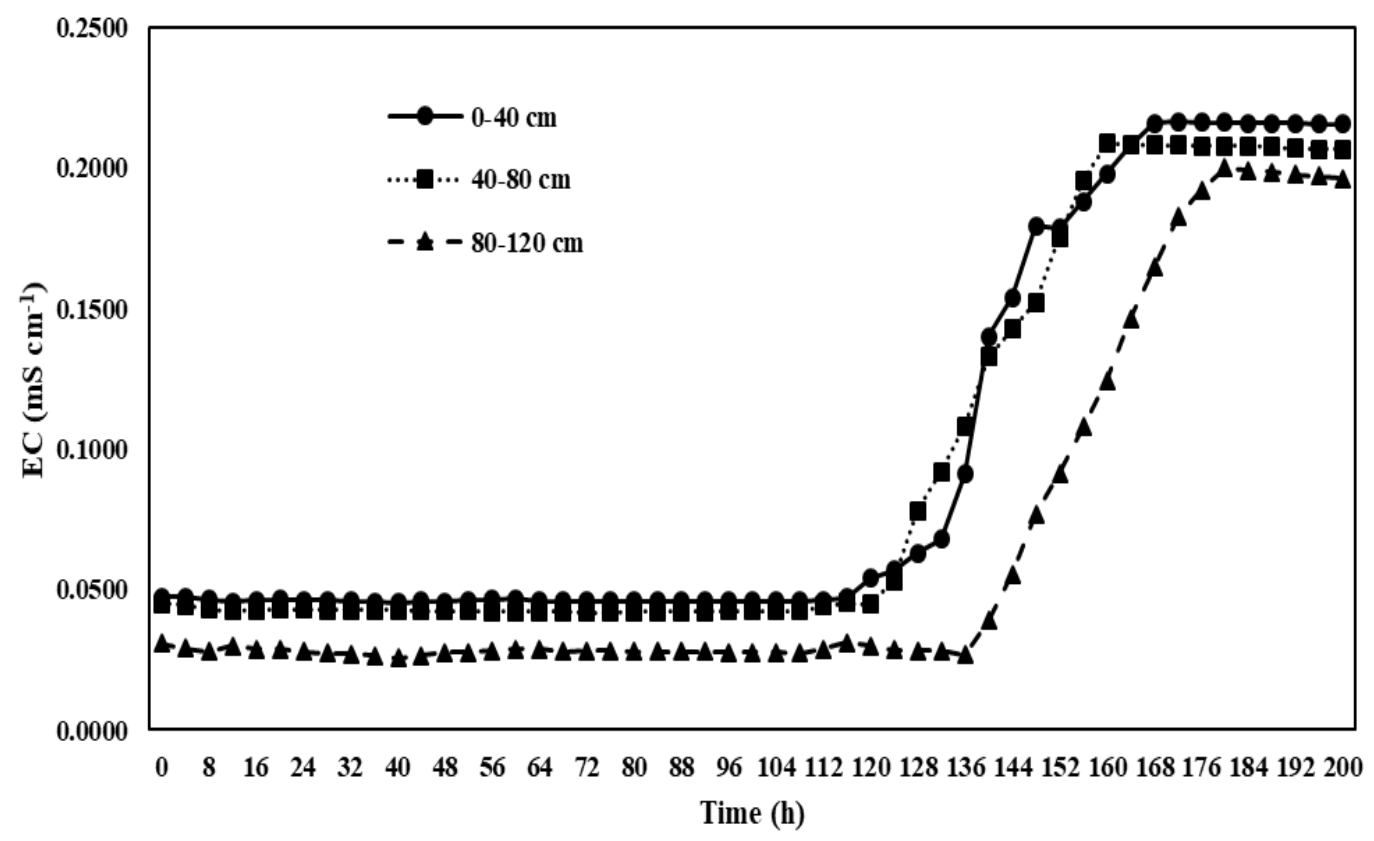


Fig.6 Subsurface Stormflow Velocity Versus Dry Density Graph

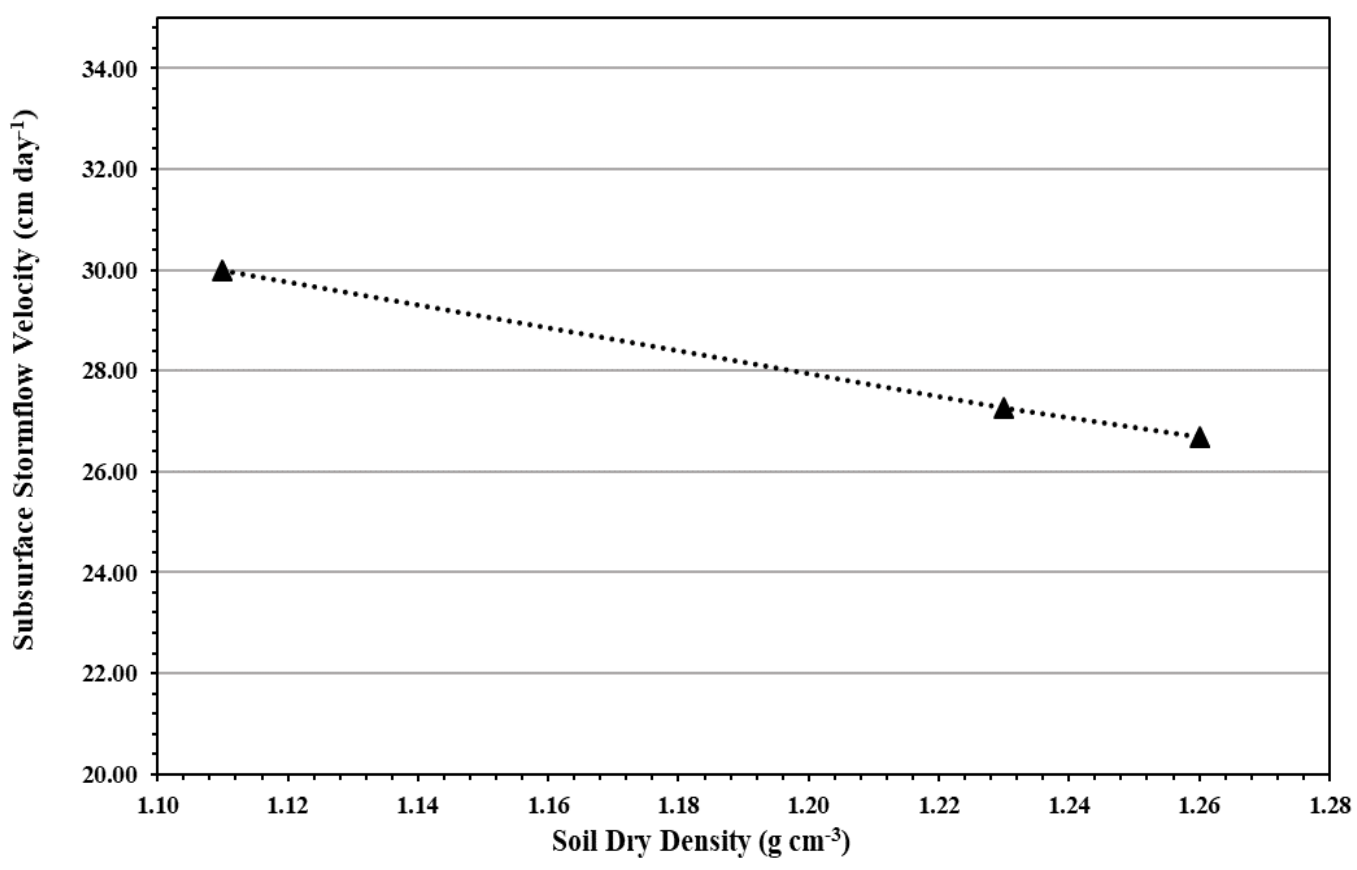

\section{References}

Ahuja, L.R. and Lehman, O.R. 1985. Interflow of water and tracer chemical on sloping field plots with exposed seepage faces. J. Hydrol. 76: 307-317.

Hewlett, J.D. and Hibbert, A.R., 1967. Factors affecting the response of small watersheds to precipitation in humid areas. Forest hydrol. 1: 275-290.

Knöll, P. and Scheytt, T. 2018. A tracer test to determine a hydraulic connection between the Lauchert and Danube karst catchments (Swabian Alb, Germany). Hydrogeol J. 26(2):429-437.

Leibundgut, C. and Seibert, J. 2011. Tracer
Hydrology. Treatise on Water Science 2: 215-236.

Rodhe, A. 1981. Spring Flood Meltwater or Groundwater? Paper presented at the Nordic Hydrological Conference (Vemdalen, Sweden, August, 1980). Hydrology Research, 12(1):2130.

Tirumalesh, K., Shivanna, K., Noble, J., Narayan, K. and Xavier, K. 2007. Nuclear techniques to investigate source and origin of groundwater pollutants and their flow path at Indian Rare Earths Ltd., Cochin, Kerala. Journal of Radioanalytical and Nuclear Chemistry, 274(2):307-313.

\section{How to cite this article:}

Adarsh, S.S., Jyothy Narayanan and Sathian. 2019. Determination of Subsurface Stormflow Velocity Using Tracer. Int.J.Curr.Microbiol.App.Sci. 8(12): 2577-2584.

doi: https://doi.org/10.20546/ijcmas.2019.812.301 